\title{
ANALISIS USAHATANI PEMBIBITAN KELAPA SAWIT DI KELURAHAN KEMPAS JAYA
}

\author{
Yeni Afiza ${ }^{1}$, Sugeng Pranoto ${ }^{1}$ \\ ${ }^{1}$ Program Studi Agribisnis Fakultas Pertanian UNISI \\ Email : yeni_afiza@yahoo.co.id
}

\begin{abstract}
ABSTRAK
Tujuan penelitian untuk mengetahui besarnya biaya produksi, penerimaan, dan pendapatan usahatani dari pembibitan kelapa sawit di Kelurahan Kempas Jaya dan mengetahui efisiensi dari usahatani pembibitan kelapa sawit di Kelurahan Kempas Jaya. Metode analisis yang digunakan adalah analisisbiaya total, penerimaan, pendapatan, pendapatan kerja keluarga, penyusutan alat, dan efisiensi. Hasil penelitian ini menunjukan bahwa penerimaan yang diperoleh oleh petani pembibitan satu tahap sebesar Rp 36.750.000/MT dan dua tahap sebesar Rp 36.750.000/MT. Pendapatan petani satu tahap sebesar Rp 23.554.752./MT dan dua tahap sebesar Rp 24.761.600/MT. Pendapatan kerja keluarga satu tahap sebesar Rp 23.868.000/MT dan dua tahap sebesar Rp 25.401.250/MT. Return cost Ratio (RCR) usahatani pembibitan kelapa sawit satu tahap diperoleh sebesar 2,78dan dua tahap sebesar 3,06.Berdasarkan nilai efisiensi yang diperoleh maka usahatani pembibitan kelapa sawit satu tahap dan dua tahap sudah efisien.
\end{abstract}

Kata Kunci : usahatani, kelapa sawit, pembibitan, efisiensi

\section{PENDAHULUAN}

Provinsi Riau merupakan provinsi dengan areal perkebunan kelapa sawit yang terluas diIndonesia yakni 1,78 juta Ha pada tahun 2010 atau 20,82 persen dari total luas areal perkebunan kelapa sawit di Indonesia dan pada tahun 2011 luas perkebunan kelapa sawit di Provinsi Riau ialah 1,79 juta Ha.Dari total luasan perkebunan kelapa sawit di Riau yang terbesar adalah milik perkebunan rakyat yang mencapai 53 persen, menyusul perkebunan perusahaan besar swasta 40,9 persen dan sisanya 6,1 persenmerupakan perkebunan yang dikelola perusahaan besar negara (BPS, 2011).

Meskipun perkebunan petani rakyat yang terluas, akan tetapi dari hasil produksi, baik dari segi kualitas dan kuantitas, perkebunan kelapa sawit petani swadaya tetap saja kalah jika dibanding hasil produksi perusahan besar negara dan perusahaan swasta. Produksi perkebunan petani rakyat rata-rata hanya 11,4 ton per hektar per tahun. Artinya, tidak sampai satu ton per hektarenya dalam setiap bulan. Hampir seluruh produksi TBS petani rakyat mempunyai rendemen di bawah standar.Kondisi demikin disebabkan banyak faktor, mulai dari kealpaan menggunakan bibit hingga minimnya perawatan serta lemahnya manejemen kebun.Untuk mengatasi permasalahan diatas salah satu nya adalah perlunya untuk penyedian bibit yang unggul(BPS, 2011). 
Perkembangan perkebunan kelapa sawit ini dapat direalisasikan apabila tersedia bibit kelapa sawit yang memadai untuk memenuhi kebutuhan yang diperlukan. Oleh sebab itu tidak mengherankan apabila akhir-akhir ini banyak rumah tangga keluarga mengusahakan pembibitan kelapa sawit. Hal ini didukung oleh tanaman kelapa sawit itu sendiri sangat cocok untuk dibudidayakan.

Salah satu daerah yang melakukan usahatani pembibitan kelapa sawit adalah Kelurahan Kempas Jaya Kabupaten Indragiri Hilir. Walaupun usaha tersebut sebagai kerja sampingan tetapi dapat memberikan keuntungan dan membantu perekonomian keluarga. Rata-rata lahan pembibitan kelapa sawit yang digunakan lahan pribadi atau sendiri yang memanfaatkan sekitar rumah.

Usaha pembibitan kelapa sawit membutuhkan modal yang besar namun memiliki peluang pasar yang cukup luas. Sehingga perlu dilakukan analisis usahatani yang tepat sehingga pendapatan dan efisiensi usahatani dapat diketahui. Berdasarkan uraian diatas maka tujuan penelitian ini adalah untuk mengetahui besarnya biaya produksi, penerimaan, dan pendapatanusahatani dari pembibitan kelapa sawit di Kelurahan Kempas Jaya dan untuk mengetahui nilai efisiensi dari usahatani pembibitan kelapa sawit tersebut.

\section{TINJAUAN PUSTAKA \\ 2.1. Kelapa Sawit}

Nama latin dari kelapa sawit adalah Elaeis guineensis Jacq. Elaeis berasal dari kata Elaion yang berarti minyak dalam bahasa Yunani dan
Guineensis berasal dari kata Guinea yaitu pantai Barat Afrika. Jacq berasal dari nama ahli botani (botanist) Amerika bernama Jacquin (Setyamidjaja, 2006).

Tanaman kelapa sawit merupakan salah satu komoditi perkebunan yang memiliki nilai jual yang cukup tinggi dan penyumbang devisa terbesar bagi negara Indonesia dibandingkan dengan komoditi perkebunan lainnya. Setiap tanaman memiliki morfologi yang berbedabeda cirinya dan fungsinya. Sehingga pada budidaya tanaman kelapa sawit memerlukan pengetahuan awal terlebih dahulu mulai dari morfologinya sebelum melakukan budidaya. Tanaman kelapa sawit secara morfologi terdiri atas bagian vegetatif (akar, batang, dan daun) dan bagian generatif (bunga dan buah).

Kelapa sawit tumbuh dengan baik pada daratan rendah di daerah tropis yang beriklim basah, yaitu sepanjang garis yang khatulistiwa antara 23,5 LU-23,5 LS (Pahan, 2008). Persiapan pembibitan menentukan sistem pembibitan yang akan dipakai dengan melihat keuntungan dan kerugian secara baik. Keputusan menggunakan di sistem pembibitan dua tahap misalnya akan membawa dampak pada vigor bibit yang akan dihasilkan dan biaya yang harus dikeluarkan (Pahan, 2008).

Proses pembibitan dapat dilakukan dengan satu tahap atau dua tahap pekerjaan. Pembibitan satu tahap berarti kecambah kelapa sawit langsung ditanam di polibag besar atau langsung di pembibitan utama (main nursery). Pembibitan dua tahap artinya penanaman kecambah dilakukan dalam di pembibitan awal (prenursery) yang terlebih dahulu 
menggunakan polibag kecil serta naungan, kemudian dipindahkan ke main nursery ketika berumur 3-4 bulan di dalam menggunakan polibag yang lebih besar (Pahan, 2008).

\subsection{Analisis Usaha Tani}

Menurut Soekartawi (2006) ilmu usahatani diartikan sebagai ilmu yang mempelajari bagaimana seseorang untuk mengalokasikan sumberdaya yang ada secara efektif dan efisien dengan melakukan yang perhitungan ekonomis terhadap usahatani yang dilakukan. Perhitungan ini yang untuk memberikan gambaran apakah usaha yang dilakukan memberikan keuntungan atau sebaliknya. Beberapa hal yang harus di perhatikan dalam menganalisis untuk suatu kegiatan usahatani adalah penggunaan faktor produksi, penggunaan biaya produksi, untuk melihat produksi yang dihasilkan serta melihat tingkat penerimaan atau pendapatan. Parameter pendapatan usaha tani adalah penerimaan usaha tani, biaya usaha tani dan pendapatan usaha tani (Powa, dkk, 2011)

Menurut Yasin (2002) ada dua faktor produksi mempengaruhi peningkatan produksi pertanian yaitu: faktor produksi tetap dan faktor produksi variabel. Faktor produksi tetap ini terdiri dari tanah, bangunan, dan penyusutan alat-alat pertanian. Faktor produksi perlu di perhatikan dalam usaha tani adalah lahan, modal dan tenaga kerja (Soekartawi , 2003).

\subsection{Efisiensi Usahatani}

Efisiensi diartikan sebagai upaya mengalokasikan input untuk mendapatkan produksi yang maksimal. Tingkat efisiensi usahatani dapat dinilai dari hasil perbandingan antara nilai keluaran (output) dan nilai masukan (input). Dalam analisis ekonomi, efisiensi bertindak sebagai alat ukur untuk mengukur atau mengetahui keuntungan dari usaha.

\section{METODE PENELITIAN}

\subsection{Tempat dan Waktu Penelitian}

Penelitian dilaksanakan di

Kelurahan Kempas Jaya Kecamatan Kempas. Pemilihan tempat didasarkan pada alasan bahwa Kelurahan Kempas Jaya merupakan daerah yang banyak mengusahakan pembibitan kelapa sawit. Penelitian dilakukan pada bulan Juni sampai dengan Agustus 2016.

\subsection{Jenis dan Sumber Data}

Jenis data dalam penelitian ini adalah data primer dan data sekunder. Data primer diperoleh dari petani yang mengusahakan pembibitan kelapa sawit, meliputi produksi, banyaknya faktor-faktor produksi yang digunakan, dan karakteristik petani seperti umur, tingkat pendidikan. Data sekunder diperoleh dari lembaga atau instansi yang terkait meliputi, Badan Pusat Statistik ( BPS ), Dinas perkebunan, buku-buku, jurnal, dan laporanlaporan hasil penelitian yang relevan dengan penelitian ini.

\subsection{Populasi dan Sampel}

Berdasarkan survey, jumlah petani yang mengusahakan pembibitan kelapa sawit secara komersial sebanyak 10 orang. Penentuan sampel dalam penelitian ini dilakukan secara acak sederhana (random sampling) yaitu dari 10 orang petani, sampel diambil sebesar 30\%. Berdasarkan hasil tersebut diperoleh 3 sampel. Dari 3 sampel tersebut terdiri dari 2 sampel 
yang menggunakan sistem pembibitan 2 tahap dan 1 sampel

\subsection{Metode Analisis}

Penerimaan usaha tani di defenisikan sebagai nilai dari total produksi dari suatu usaha tani dalam jangka waktu tertentu baik yang dijual maupun tidak di jual. Cara untuk menghitung penerimaan dapat dilakukan dengan mengalikan jumlah produk dengan harga jual produk per unit. Jika dirumuskan sebagai berikut:

$$
\text { TR = Py x Y }
$$

Keterangan:

$\mathrm{TR}=$ Total penerimaan $(\mathrm{Rp} / \mathrm{MT})$

$\mathrm{Py}=$ Harga jual (Rp/Batang)

$\mathrm{Y}=$ Jumlah produksi (Batang)

\subsubsection{Biaya Total}

Biaya Total (TC) yaitu biaya yang dikeluarkan untuk proses produksi yang terdiri atas biaya tetap (FC) dan biaya tidak tetap (VC). Biaya tetap adalah biaya yang besar kecilnya tidak tergantung pada besar kecilnya produksi, misalnya sewa atau bunga tanah yang berupa uang.Biaya tidak tetap adalah biaya yang besar kecilnya berhubungan langsung dengan besarnya produksi, misalnya pengeluaran untuk bibit, pupuk, dan sebagainya (Sukirno, 2006).

$$
\mathrm{TC}=\mathrm{TFC}+\mathrm{TVC}
$$

Keterangan:

$\mathrm{TC}=$ Biaya total $(\mathrm{Rp} / \mathrm{MT})$

TFC $=$ Total biaya tetap $(\mathrm{Rp} / \mathrm{MT})$

$\mathrm{TVC}=$ Total biaya variabel $(\mathrm{Rp} / \mathrm{MT})$

\subsubsection{Pendapatan}

Pendapatan merupakan pengurangan dari penerimaan dengan biaya total. Menurut Hernanto (1994), besarnya pendapatan yang akan diperoleh dari suatu kegiatan usahatani tergantung dari beberapa menggunakan sistem pembibitan 1 tahap.

\subsubsection{Penerimaan}

faktor yang mempengaruhinya seperti luas lahan, tingkat produksi, identitas pengusaha, pertanaman, dan efisiensi penggunaan tenaga kerja. Dalam melakukan kegiatan usahatani, petani berharap dapat meningkatkan pendapatannya sehingga kebutuhan hidup sehari-hari dapat terpenuhi.

$$
\mathrm{Pd}=\mathrm{TR}-\mathrm{TC}
$$

Keterangan:

$\mathrm{Pd}=$ Pendapatan $(\mathrm{Rp} / \mathrm{MT})$

$\mathrm{TR}=$ Total penerimaan $(\mathrm{Rp} / \mathrm{MT})$

$\mathrm{TC}=$ Total cost $(\mathrm{Rp} / \mathrm{MT})$

\subsubsection{Analisis Pendapatan Kerja Keluarga}

Untuk pendapatan kerja keluarga digunakan rumus menurut Hermanto (1991), yaitu:

$$
\mathrm{PKK}=\pi+\mathrm{K}+\mathrm{D}
$$

Keterangan:

$$
\begin{aligned}
\text { PKK }= & \text { Pendapatan Kerja Keluarga } \\
& (\text { Rp/MT }) \\
\Pi= & \text { Pendapatan Bersih }(\text { Rp } / M T) \\
\mathrm{K}= & \text { Upah Tenaga Kerja Dalam } \\
& \text { Keluarga (RP/MT) } \\
\mathrm{D}= & \text { Depresiasi (Penyusutan) } \\
& (\text { Rp/MT })
\end{aligned}
$$

\subsubsection{Analisis Penyusutaan Alat}

Untuk menghitung biaya penyusutan alat-alat pertanian, digunakan metode penyusutan garis lurus ( staight line method) menurut Sinuraya (1995), yaitu :

$$
\mathrm{D}=\frac{\mathrm{C}-\mathrm{SV}}{\mathrm{UL}}
$$

Keterangan :

$\mathrm{D}=$ Nilai penyusutan

$\mathrm{C}=$ Nilai beli alat

SV $=$ Nilai sisa alat $(20 \%$ dari nilai beli)

$\mathrm{UL}=$ Umur ekonomis 


\subsubsection{Efisiensi}

Menurut Sudarsono (1995), efisiensi diartikan sebagai upaya mengalokasikan input untuk mendapatkan produksi yang maksimal. Tingkat efisiensi usahatani dapat dinilai dari hasil perbandingan antara nilai keluaran (output) dan nilai masukan (input). Dalam analisis ekonomi, efisiensi bertindak sebagai alat ukur untuk mengukur atau mengetahui keuntungan dari usaha.

$$
\mathrm{R} / \mathrm{C}=\mathrm{TR} / \mathrm{TC}
$$

Keterangan:

$\mathrm{R} / \mathrm{C}=$ Perbandingan penerimaan dan Biaya (Rp/MT)

$\mathrm{TR}=$ Total penerimaan $(\mathrm{Rp} / \mathrm{MT})$

$\mathrm{TC}=$ Biaya Total $(\mathrm{Rp} / \mathrm{MT})$

Kriteria :

Jika R/C > 1, maka usaha tani pembibitan kelapa sawit efisien

Jika $\mathrm{R} / \mathrm{C}<1$, maka usaha tani pembibitan kelapa sawit tidak efisien Jika $\mathrm{R} / \mathrm{C}=1$, maka usaha tani pembibitan kelapa sawit BEP.

\section{HASIL DAN PEMBAHASAN \\ 4.1. Faktor Produksi \\ 4.1.1. Lahan}

Lahan merupakan salah satu faktor produksi utama yang harus ada disamping tenaga kerja dan modal yang dialokasikan untuk usaha pertanian. Berdasarkan hasil penelitian dilapangan, diperoleh data bahwa luas lahan yang digunakan dalam usahatani pembibitan kelapa sawit adalah 1-1,5Ha. Jarak tanam yang digunakan dalam pembibitan satu tahap adalah $50 \times 50 \mathrm{~cm}$ sedangkan jarak tanam pada pembibitan dua tahap adalah $60 \times 60 \mathrm{~cm}$

\subsubsection{Modal}

Modal merupakan faktor yang sangat penting untuk memulai usaha dan modal berfungsi sebagai biaya untuk pembelian sarana produksi, besar kecilnya modal yang dibutuhkan petani tergantung pada luas lahan dan digunakan dalam usahataninya, berkaitan biaya yang dikeluarkan baik biaya tetap maupun tidak tetap. Dalam penelitian ini modal usaha yang digunakan bersumber dari modal petani sendiri.

Modal yang dibutuhkan untuk 10.000 bibit kelapa sawit pada sistem pembibitan satu tahap adalah sebesar Rp.131.952.480/MT. Dengan demikian dapat diketahui bahwa biaya rata-rata bibit/batang Rp.13.195,24. Sedangkan modal yang dibutuhkan untuk pembibitan kelapa sawit pada sistem dua tahap adalah Rp.71.930.400/MT. Dengan produksi bibit sebanyak 6.000 batang maka dapat diketahui biaya rata-rata bibit/batang adalah Rp.11.988,4.

\subsubsection{Tenaga Kerja}

Tenaga kerja pada penelitian ini terdiri dari tenaga kerja pria, tenaga kerja wanita dan tenaga kerja anak. Untuk tenaga kerja anak bersifat borongan yaitu pada pengisian polybag. Untuk borongan pengisian polybag kecil yaitu Rp.100/polybag sedangkan pada polybag besar Rp.300/polybag. Untuk tenaga kerja pria dan wanita bersifat harian dengan jumlah jam kerja 8 jam/hari dengan biaya upah Rp.80.000 dan untuk biaya pengangkutan bibit juga bersifat borongan yaitu Rp.500/batang

Sedangkan untuk tenaga kerja pada tahap kerja penyiraman yaitu pada awal-awal penanaman atau pada prenursery dilakukan penyiraman setiap hari selama 3 
bulan, untuk pembibitan sistem satu tahap sehari penyiraman membutuhkan waktu 3 jam, sedangkan untuk satu hari orang kerja menghabiskan waktu 8 jam, maka akan didapat selama 3 bulan itu 35 hari orang kerja. Pada sistem dua tahap sehari membutuhkan waktu 1 jam kerja untuk menyiram maka selama 3 bulan itu akan didapat 12 HOK.

\subsection{Analisis Data}

\subsubsection{Biaya Total}

Biaya Total (TC) yaitu biaya yang di keluarkan untuk proses produksi yang terdiri atas biaya tetap (FC) dan biaya tidak tetap (VC). Biaya tetap adalah biaya yang besar kecilnya tidak tergantung pada besar kecilnya produksi, misalnya sewa atau bunga tanah yang berupa uang. Biaya tidak tetap adalah biaya yang besar kecilnya berhubungan langsung dengan besarnya produksi, misalnya pengeluaran untuk bibit, pupuk, dan sebagainya (Sukirno, 2006). Biaya total responden adalah penjumlahan dari biaya tetap dan biaya tidak tetap, Baik itu biaya benih, biaya pupuk, biaya herbisida, biaya tenaga kerja, biaya penyusutan alat, dan biaya lain-lain. Berikut ini adalah biaya total yang harus dikeluarkan oleh responden yang menggunakan sistem pembibitan satu tahap dalam pembibitan kelapa sawit di Kelurahan Kempas Jaya.

Pada tabel 1 terlihat bahwa biaya total yang dikeluarkan oleh responden pada pembibitan Kelapa sawit yang menggunakan sistem satu tahap adalah sebesar Rp131.952.480 /MT. Dari biaya produksi tersebut, untuk biaya Variabel adalah sebesar Rp 130.810.000/MT. Dan Biaya Tetap sebesar Rp1.142.480/MT. Biaya yang sangat besar dikeluarkan adalah pada biaya variabel yaitu pada biaya pembelian kecambah sebesar Rp.90.000.000/MT. Kemudian untuk pembibitan yang menggunakan sistem dua tahap adapun biaya biaya yang harus dikeluarkan dalam pembibitan kelapa sawit bisa dilihat pada tabel 2 .

Tabel 1. Biaya Variabel dan Biaya Tetap Usahatani Yang Menggunakan Sistem Satu Tahap Pada Pembibitan Kelapa Sawait Di Kelurahan Kempas Jaya

\begin{tabular}{|c|c|c|}
\hline No & Uraian & Nilai \\
\hline \multirow[t]{10}{*}{1} & Biaya Variabel & \\
\hline & Kecambah (Rp) & 90.000 .000 \\
\hline & Polibag (Rp) & 6.500 .000 \\
\hline & Tanah $(\mathrm{Rp})$ & 8.000 .000 \\
\hline & Pupuk Kandang (Rp) & 400.000 \\
\hline & Pupuk Kimia (Rp) & 12.650 .000 \\
\hline & Herbisida (Rp) & 300.000 \\
\hline & Tenaga Kerja Dalam Keluarga (Rp) & 3.040 .000 \\
\hline & Tenaga Kerja Luar Keluarga (Rp) & 9.920 .000 \\
\hline & Jumlah & 130.810 .000 \\
\hline \multirow[t]{5}{*}{2} & Biaya Tetap & \\
\hline & Penyusutan Alat (Rp) & 92.480 \\
\hline & Kawat (Rp) & 1.050 .000 \\
\hline & Jumlah & 1.142 .480 \\
\hline & Biaya Total & 131.952 .480 \\
\hline
\end{tabular}


Pada tabel 2 dapat dilihat bahwa rata-rata biaya variabel pada pembibitan kelapa sawit sistem dua tahap adalah sebesar Rp 71.362.500/MT. Rata-rata biaya tetap sebesar Rp 567.900/MT maka ratarata biaya total yang di keluarkan untuk pembibitan yang menggunakan sistem dua tahap adalah sebesar Rp 71.930.400/MT. Perbedaan dari kedua sisitem pembibitan ini adalah untuk pembibitan satu tahap dapat mengirit biaya polybag dan biaya tenaga kerjanya, karna pada pembibitan satu tahap tidak menggunakan polybag kecil.

Tabel 2. Biaya Variabel dan Biaya Tetap UsahaTani Yang Menggunakan Sistem Dua Tahap Pada Pembibitan Kelapa Sawait Di Kelurahan Kempas Jaya

\begin{tabular}{|c|c|c|}
\hline No & Uraian & Nilai \\
\hline \multirow[t]{11}{*}{1} & Biaya Variabel & \\
\hline & Kecambah (Rp) & 108.000 .000 \\
\hline & Polibag (Rp) & 8.750 .000 \\
\hline & Tanah (Rp) & 8.000 .000 \\
\hline & Pupuk Kandang (Rp) & 300.000 \\
\hline & Pupuk Kimia (Rp) & 5.585 .000 \\
\hline & Herbisida (Rp) & 250.000 \\
\hline & Tenaga Kerja Dalam Keluarga (Rp) & 7.520 .000 \\
\hline & Tenaga Kerja Luar Keluarga (Rp) & 4.320 .000 \\
\hline & Jumlah & 142.725 .000 \\
\hline & Rata-rata & 71.362 .500 \\
\hline \multirow[t]{6}{*}{2} & Biaya Tetap & \\
\hline & Penyusutan Alat (Rp) & 155.800 \\
\hline & Jaring Pagar (Rp) & 980.000 \\
\hline & Jumlah & 1.135 .800 \\
\hline & Rata-rata & 567.900 \\
\hline & Biaya Total & 71.930 .400 \\
\hline
\end{tabular}

Sumber : data primer di olah 2016

\subsubsection{Penerimaan}

Penerimaan usahatani di definisikan sebagai nilai dari total produksi dari suatu usahatani dalam jangka waktu tertentu baik yang di jual maupun yang tidak di jual. Cara untuk menghitung penerimaan dapat di lakukan dengan mengalikan jumlah produk dengan harga jual. Produksi bibit kelapa sawit pada sistem satu tahap adalah 10.000 bibit, dari 10.000 tersebut terdapat $2 \%$ yang mati atau afkir sehingga tersisa bibit 9.800 bibit. Sedangkan untuk yang sisstem dua tahap memproduksi bibit sebanyak 6.000 bibit dan terdapat pula $2 \%$ bibit yang mati sehingga tersisa bibit sebanyak 5.880 bibit. Penerimaan responden dalam usaha tani pembibitan kelapa sawit di Kelurahan Kempas Jaya bisa di lihat pada tabel 3 .

Pada tabel terlihat bahwa besarnya tingkat penerimaan yang diperoleh oleh responden tergantung kepada besarnya produksi serta harga jual dan total biaya produksi. Produksi yang dihasilkan responden yang menggunakan sistem 
pembibitan satu tahap adalah 9.800 batang/MT. Harga jual perbatang Rp 37.500/batang, sehingga penerimaan sebesar Rp 36.750.000/MT/1000 batang. Produksi responden yang menggunakan sistem pembibitan dua tahap adalah 5.880 batang/MT dengan harga jual Rp 37.500/batang. Sehingga diperoleh penerimaan sebesar 36.750.000/MT/1000 batang.

Tabel 3.Penerimaan Responden Dalam Pembibitan Kelapa Sawit/Musim Tanam.

\begin{tabular}{|c|c|c|c|c|c|c|}
\hline $\mathrm{No}$ & \multicolumn{5}{|c|}{ Pembibitan Sistem Satu Tahap } & \multirow{2}{*}{$\begin{array}{l}\text { Penerimaan/ } \\
1000 \text { batang }\end{array}$} \\
\hline 1 & Produksi & Afkir & $\begin{array}{c}\text { Produk } \\
\text { Yang } \\
\text { Di Jual }\end{array}$ & $\begin{array}{c}\text { Harga } \\
\text { Bibit/Batang } \\
\text { (Rp) }\end{array}$ & $\begin{array}{c}\text { Penerimaan } \\
\text { (Rp) }\end{array}$ & \\
\hline & 1.000 & 200 & 9.800 & 37.500 & 367.500 .000 & 36.750 .000 \\
\hline & \multicolumn{5}{|c|}{ Pembibitan Sistem Dua Tahap } & \\
\hline 2 & Produksi & Afkir & $\begin{array}{c}\text { Produk } \\
\text { Yang } \\
\text { Di Jual }\end{array}$ & $\begin{array}{c}\text { Harga } \\
\text { Bibit/Batang } \\
(\mathrm{Rp})\end{array}$ & $\begin{array}{c}\text { Penerimaan } \\
\text { (Rp) }\end{array}$ & $\begin{array}{l}\text { Penerimaan/ } \\
1000 \text { batang }\end{array}$ \\
\hline & 6.000 & 120 & 5.880 & 37.500 & 220.500 .000 & 36.750 .000 \\
\hline
\end{tabular}

Sumber : Data Olahan 2016

\subsubsection{Pendapatan}

Pendapatan

merupakan pengurangan dari penerimaan dengan biaya total. Menurut Hermanto (1994), besarnya pendapatan yang akan di peroleh dari suatu kegiatan usahatani tergantung dari beberapa faktor yang mempengaruhinya seperti luas lahan, tingkat produksi, dan efisiensi penggunaan tenaga kerja. Pendapatan responden dalam usahatani pembibitan kelapa sawit bisa di lihat pada tabel 4. Pada tabel terlihat bahwa pendapatan yang diterima oleh responden yang menggunakan sistem pembibitan satu adalah $\quad \mathrm{Rp} \quad 23.554 .752 / \mathrm{MT} / 1000$ batang. Sedangkan pendapatan untuk responden yang menggunakan sistem pembibitan dua tahap adalah $\mathrm{Rp}$ 24.761.600/MT/1000 batang. Pendapatan diperoleh dari penerimaan dikurang dengan biaya total. Pada penelitian ini pendapatan pada pembibitan dua tahap lebih besar jika dibandigkan dengan pendapatan satu tahap. Hal ini di akibatkan karna penggunaan input produksi dan pada pembibitan satu tahap ada biaya pengangkutan yang harus dikeluarkan.

Tabel 4. Pendapatan Responden Dalam Pembibitan Kelapa Sawit

\begin{tabular}{|c|c|c|c|c|}
\hline No & \multicolumn{3}{|c|}{ Satu Tahap } & \multirow{2}{*}{$\begin{array}{c}\text { Konversi/ } \\
\text { 1000 Batang }\end{array}$} \\
\hline 1 & Penerimaan & Total Biaya & Pendapatan & 23.554 .752 \\
\hline & 367.500 .000 & 131.952 .480 & 235.547 .520 & \\
\hline 2 & \multicolumn{3}{|c|}{ Dua Tahap } \\
\hline & 220.500 .000 & 71.930 .400 & 148.569 .600 & 24.761 .600 \\
\hline
\end{tabular}

Sumber : Data Olahan 2016

Data pendapatan keja keluarga bisa dilihat pada tabel 5 . Pada tabel terlihat bahwa pendapatan kerja keluarga untuk satu tahap adalah sebesar Rp 23.868.000/MT/1000 batang. Dan 
pendapatan kerja keluarga pada pembibitan Dua tahap sebesar Rp 25.401.250/MT/1000 batang. Pendapatan kerja keluarga di dapat dengan cara menjumlahkan pendapatan dengan biaya kerja keluarga serta biaya penyusutan alat.

Tabel 5. Pendapatan Kerja Keluarga Dalam Pembibitan Kelapa Sawit

\begin{tabular}{|c|c|c|c|c|c|}
\hline No & \multicolumn{3}{|c|}{ Sistem Pembibitan Satu Tahap } & Konversi/ \\
\hline 1 & Pendapatan & Biaya TKDK & Penyusutan Alat & Pendapatan KK & 1000 Batang \\
\hline & 235.547 .520 & 3.040 .000 & 92.480 & 238.680 .000 & 23.868 .000 \\
\hline & \multicolumn{3}{|c|}{ Sistem Pembibitan Dua Tahap } & \\
\hline 2 & Pendapatan & Biaya TKDK & Penyusutan Alat & Pendapatan KK & \\
\hline & 148.569 .600 & 3.760 .000 & 77.900 & 152.407 .500 & 25.401 .250 \\
\hline
\end{tabular}

Sumber : Data Olahan 2016

\subsubsection{Efisiensi}

Menurut sudarso (1995), efisiensi diartikan sebagai upaya mengalokasikan input untuk mendapatkan produksi yang maksimal. Tingkat efisiensi usahatani dapat dinilai dari hasil perbandingan antara nilai keluaran (output) dan nilai masukan (input). Dalam analisis ekonomi, efisiensi bertindak sebagai alat ukur untuk mengukur atau mengetahui keuntungan dari usaha.Untuk mengetahui efisiensi usahatani pembibitan kelapa sawit pada sistem satu tahap bisa dilihat pada tabel 6 . Berdasarkan tabel dapat diketahui bahwa nilai RCR pada usahatani yang menggunakan sistem pembibitan satu tahap adalah 2,78. Nilai RCR ini berarti bahwa setiap Rp 1,00 biaya produksi untuk berusahatani pembibitan kelapa sawit akan memberikan pendapatan kotor sebesar Rp 2,78 dan pendapatan bersih sebesar 1,78. Menurut Soekartawi (2002) jika R/C > 1 berarti usahatani pembibitan kelapa sawit menguntungkan. Hasil penelitian ini menunjukan nilai RCR 2,78 yang berari ebih dari 1 sehingga dapat disimpulkan usahatani pembibitan kelapa sawit pada sistem satu tahap Efisien.

Nilai RCR pada usahatani yang menggunakan sistem pembibitan dua tahap adalah 3,06. Nilai RCR ini berarti bahwa setiap $\mathrm{Rp} 1,00$ biaya produksi untuk berusahatani pembibitan kelapa sawit akan memberikan pendapatan kotor sebesar Rp 3,06 dan pendapatan bersih sebesar 2,06. Hasil penelitian ini menunjukan nilai RCR 3,06 yang berari lebih dari 1 sehingga dapat disimpulkan usahatani pembibitan kelapa sawit pada sistem dua tahap juga Efisien. Jika di bandingkan dengan penelitiannya Muchin (2016) nilai RCR yang diperoleh sebesar 2,6. Nilai ini menunjukan bahwa usaha pembibtan kelapa sawit layak di usahakan. 
Tabel 6. Analisis Efisiensi Usaha Tani Pembibitan Kelapa Sawit di Kelurahan Kempas Jaya Pada Pembibitan Satu Tahap

\begin{tabular}{|c|c|c|c|c|c|}
\hline No & Uraian & $\begin{array}{c}\text { Nilai } \\
1 \text { Tahap }\end{array}$ & $\begin{array}{c}\text { Nilai } \\
2 \text { Tahap }\end{array}$ & $\begin{array}{c}\text { Konversi/ } \\
1000 \mathrm{btg} \\
1 \text { Tahap }\end{array}$ & $\begin{array}{c}\text { Konversi/ } \\
1000 \mathrm{btg} \\
2 \text { Tahap }\end{array}$ \\
\hline 1 & $\begin{array}{c}\text { Pendapatan Kotor/ } \\
\text { Penerimaan }\end{array}$ & 367.500 .000 & 220.500 .000 & 36.750 .000 & 36.750 .000 \\
\hline 2 & Total Biaya Produksi & 131.952 .480 & 71.930 .400 & 13.195 .248 & 11.988 .400 \\
\hline \multicolumn{2}{|r|}{} & 2,78 & 3,06 & 2,78 & 3,06 \\
\hline
\end{tabular}

Sumber : Data Olahan, 2016

\section{KESIMPULAN DAN SARAN}

\subsection{Kesimpulan}

Dari uraian dan penjelasan yang telah dikemukakan dalam hasil penelitian ini maka dapat disimpulkan sebagai berikut :

1. Biaya produksi bibit kelapa sawit pada sistem pembibitan satu tahap adalah sebesar Rp 131.952.480 batang/MT. Penerimaan yang di peroleh sebesar Rp 36.750.000/MT/1000 batang. Pendapatan responden sebesar Rp 23.554.752/MT/1000 batang. Sedangkan untuk pembibitan sistem dua tahap memerlukan biaya produksi sebesar Rp 71.930 .400 /MT. Penerimaan yang diperoleh $\mathrm{Rp} \quad 36.750 .000$ /MT/1000 batang. dan Pendapatan sebesar Rp 24.761.600 /MT/1000 batang.

2. Untuk nilai RCR pada sistem satu adalah 2,78 dan untuk sistem dua tahap sebesar 3,06. yang artinya pembibitan sistem satu tahap maupun dua tahap efisien.

\subsection{Saran}

Responden harus dapat menekan biaya produksi seperti penggunaan pupuk, dan meminimalisir biaya-biaya lainnya sehingga diharapkan dapat meningkatkan pendapatan.

\section{DAFTAR PUSTAKA}

BPS. 2011. Perkembangan Perkebunan Kelapa Sawit. Direktorat Jendral Perkebunan. Riau

Hernanto.1994.http://ilmuandinforma si.blogspot.co.id/2013/06/teor i-pendapatan.html

Pahan, Iyung. 2008. Panduan Lengkap Kelapa Sawit, Manajemen Agribisnis dari Hulu hingga Hilir.

Powa D,Baroleh J, Ruauw E. 2011. Kajian Pengelolaan Usaha Tani Kelapa Di Desa Tolombukan Kecamatan Pasan Kabupaten Minahasa Tenggara. Jurnal ASEVolume 7 Nomor 2, Mei 2011: 39-50

Setyamidjaja, D. 2006. Kelapa Sawit. Kanisius.Yogyakarta.

Sinuraya, S. 1995. Dasar-dasar Ekonometrika. Fakultas Ekonomi Universitas Sumatra Utara.Medan.

Soekartawi. 2003. Agribisnis Teori dan Aplikasinya, PT. Grafindo Persada, Jakarta.

.Soeharjo, A. Dillon, J.L and Hardaker,JB.1986. Ilmu Usaha Tani danPenelitian untuk Pengembangan Petani Kecil. UI Press. Jakarta.

Sukirno, Sadono, 2006. Makro Ekonomi Teori Pengantar, 
PT. Raja Grafindo Persada, Jakarta.
Yasin, A. Z. 2002. Masa Depan Agribisnis Riau. Pekanbaru : UNRI Press. 